\title{
The Impact of Termination Severity on Customers' Emotional, Attitudinal, and Behavioral Reactions
}

\author{
Amin Nazifi a, Dahlia El-Manstrly ${ }^{b}$, Angela Tregear ${ }^{\text {b }}$, and Kristina Auxtova ${ }^{c}$
}

\author{
Forthcoming in
}

Journal of Service Theory and Practice

Suggested Nazifi, A., El-Manstrly, D., Tregear, A., and Auxtova, K., "Customers'

citation:

Attitudinal, Emotional and Behavioural Responses to Firm-Initiated Service

Termination", Journal of Service Theory and Practice, forthcoming.

DOI: https://doi.org/10.1108/JSTP-10-2019-0224

November 10, 2020

${ }^{\text {a }}$ Strathclyde Business School, University of Strathclyde, United Kingdom

${ }^{\mathrm{b}}$ University of Edinburgh Business School, University of Edinburgh, United Kingdom

${ }^{c}$ School of Business, University of Dundee, United Kingdom

* Corresponding author:

Dr Amin Nazifi

Lecturer in Marketing,

Department of Marketing,

Strathclyde Business School,

University of Strathclyde,

199 Cathedral Street, Glasgow,

G4 0QU, UK

Tel: +441415484118

Email: amin.nazifi@strath.ac.uk 


\title{
The Impact of Termination Severity on Customers' Emotional, Attitudinal, and
}

\section{Behavioral Reactions}

\begin{abstract}
Purpose - This paper aims to empirically examine the direct and indirect effects of perceived termination severity on customers' behavioral reactions via betrayal and justice. It also examines the moderating effects of attitude towards complaining (ATC).
\end{abstract}

Design/methodology/approach - This paper employs a quantitative method approach using a scenario-based experiment in a banking setting.

Findings - The results show that a more severe termination approach results in higher customer negative reactions. Betrayal is shown to be a key driver of customers' behavioral reactions and ATC moderates these effects.

Research limitations/implications - Future studies should examine the effects of different termination strategies in markedly different cultures and should also examine other boundary conditions such as prior warning, relationship quality, and service importance in influencing customers' negative behavioral responses.

Originality/value - This paper contributes to the service termination literature by shedding light on the impact of termination severity on customers' reactions. It also unveils the mechanism that explains customers' reactions to service termination. Further, it reveals that ATC moderates customers' public (but not private) complaining behaviors.

Keywords: Firm-initiated service termination, Termination severity, Betrayal, Perceived justice, Customer complaint behavior, Revenge.

Paper type: Research paper 


\section{Introduction}

Once upon a time, every customer was king; but companies now tend to treat customers based on their merits - that is rewarding their desirable customers with royal benefits and terminating relationships with their undesirable ones (Haenlein and Kaplan, 2009). Service termination is pervasive and occurs across a wide range of industries such as finance, telecom, healthcare, and professional services (Lepthien et al., 2017, Mittal et al., 2008). One of the main reasons for service termination is lack of profitability (Haenlein and Kaplan, 2012), but other reasons include customer misbehavior which can result in employee turnover (Gong and Wang, 2019), capacity constraint, or change of strategic direction (Mittal et al., 2008). Prior research indicates that, depending on the industry, up to a third of the total customer base may be unprofitable (Haenlein and Kaplan, 2010, Niraj et al., 2001, Reinartz and Kumar, 2002). These customers which are also referred to as the "Lead" tier, at the bottom of the customer pyramid, may need to be shunned because they can have a major impact on firm financial performance (Zeithaml et al., 2001). Specifically, these bottom-tier customers can generate a loss of $50 \%$ to $200 \%$ of the total profit (Cooper and Kaplan, 1991, Narayanan and Kaplan, 2001, Shin et al., 2012). Therefore, given the significant size of these customers and their immense impact on firm's profitability, termination of these customers should be done tactfully to avoid negative word of mouth (nWOM) that can lead to the loss of other valuable customers (Casidy and Shin, 2015, Piehler et al., 2019).

While firm-initiated service termination has become increasingly popular, extant research is predominantly conceptual (Tahtinen and Halinen, 2002) or in a B2B setting (Alajoutsijärvi et al., 2000) and limited empirical studies in a B2C setting mainly focus on firm's perspective or other existing or prospective customers (Haenlein and Kaplan, 2010, Haenlein and Kaplan, 2012). Yet, without a more comprehensive understanding of terminated customers' reactions to service termination and whether the process can be better 
managed, it may seem premature to advocate service termination as a sound business practice (Haenlein et al., 2007, Kabue et al., 2015).

Firms can use various strategies to terminate customer relationships, but there is limited research on the perceived severity of different termination strategies and their subsequent negative consequences in a B2C context. An exception is a study by Haenlein and Kaplan (2011) which found no significant difference between direct and indirect hard termination strategies among other existing and prospective customers. One possible explanation for Haenlein and Kaplan's finding is that customers' reactions are, to a great extent, a function of the orientation or hardness (i.e., hard vs. soft) rather than directness (direct vs. indirect) of the termination strategy. In a hard termination approach, the firm focuses on self-interest, by ending the customer relationship with no opportunity for negotiation or any regard for the customer (Alajoutsijärvi et al., 2000). For instance, HSBC, JP Morgan, and TCF have stopped providing banking services to some of their clients without prior notice or explanation (e.g. see King, 2013). On the other hand, in a soft approach, the firm aims to end the relationship amicably by considering the needs of the customer and offering assistance with the transition to a different provider (Mittal et al., 2008). It appears that a soft approach may be perceived as less severe leading to lower negative consequences in the long term, but this has not been empirically tested.

This research addresses this issue by comparing the perceived severity and consequences of different termination strategies on customers' attitudinal (i.e., justice), emotional (i.e., betrayal), and behavioral (i.e., complaint and revenge) reactions. Here, termination severity refers to the degree of pain inflicted upon customers by the choice of termination strategy (Haenlein and Kaplan, 2009, Haenlein and Kaplan, 2012). Hence, a distinction is proposed between a more severe (i.e., hard) and a less severe (i.e., soft) termination approach. 
Accordingly, this research makes three contributions to the service termination literature. First, it responds to calls for research by Alajoutsijärvi et al. (2000), Mittal et al. (2008), and Haenel et al. (2019) on the differential impact of a soft (versus hard) termination strategy. It examines the perceived severity of these two termination strategies and their differential effect on key customer behavioral outcomes such as direct complaint, third party complaint, and nWOM as well as revenge. Hence, this study extends the work of Haenlein and Kaplan (2011) by showing that the hardness (rather than the directness) dimension of termination strategies plays a key role in the perceived severity and subsequent negative behavioral reactions to different termination strategies.

Second, drawing on expectancy violation theory (EVT), it unveils the mechanism that explains the customers' reactions to service termination. Existing studies highlight the role of perceived justice in mediating customers' behavioral reactions to termination (Haenlein and Kaplan, 2010, Lepthien et al., 2017). While perceived justice is shown to be a strong predictor of customers' behavioral responses to conventional failures (Gong et al., 2014), little is known about other drivers of customers' behavioral responses in service termination (Haenel et al., 2019). Prior research suggests that following service termination, customers often feel betrayed (Mittal et al., 2008). Similarly, Lepthien et al. (2017) highlight the importance of negative emotions in driving customers' reactions to termination but this has not been empirically tested following different termination strategies. Therefore, examining the mediating roles of justice and betrayal can provide a better picture of the effects of termination on customers' negative reactions.

Third, this study examines a boundary condition for the effects of termination severity on customers' behavioral responses. In doing so, it builds on the works of Voorhees and Brady (2005) and De Matos et al. (2009) by examining the moderating effects of attitude towards complaining (ATC). Prior research suggests that people with higher ATC tend to 
display significantly higher negative reactions to conventional failures, but this important customer-related boundary condition has not been empirically tested in a termination context. Therefore, this paper extends the service termination literature by examining the moderating role of ATC on the effects of termination severity on customers' behavioral reactions.

\section{Literature review}

\subsection{Expectancy Violation Theory}

Expectancy violation theory (EVT) specifies that due to conformity of most behaviors to people's expectations, they will go unnoticed; but those which don't can influence people's emotions and evaluations and subsequently drive their behavioral responses (Bachman and Guerrero, 2006, Bettencourt and Manning, 2016). Compared with expectancy confirmation, positive violations (i.e., positive disconfirmations) result in more desirable outcomes whereas negative violations (i.e., negative disconfirmations) can be detrimental (Burgoon, 1993). Previous research provides support for a positive relationship between negative violation and negative emotions such as betrayal (Bachman and Guerrero, 2006) and a negative relationship between negative violation and justice (Schoefer and Ennew, 2005). According to Bachman and Guerrero (2006), hurtful actions that reflect the devaluation of a relationship such as breakups are considered negative violations. Transferred to a service termination context, a unilateral and unexpected closure of customer accounts represents a relational negative violation that can cause negative emotional and behavioral reactions.

\subsection{Perceived termination severity}

Perceived failure severity which refers to the perceived magnitude or intensity of the failure (Balaji and Sarkar, 2013) is shown to influence post failure's emotional, attitudinal, and behavioral reactions (Swanson and Hsu, 2009). In this study, termination severity refers to the perceived magnitude of harm inflicted upon customers by the choice of termination 
strategy (Haenlein and Kaplan, 2009, Haenlein and Kaplan, 2012). Drawing on EVT, the severity of a negative violation is shown to have a positive impact on the intensity of the negative emotions and subsequent behaviors (Afifi and Metts, 1998, Bettencourt and Manning, 2016).

Transferred to a termination context, the severity of termination strategy (in terms of inflicted harm upon customers) can play an important role in driving subsequent emotional and behavioral reactions. In terms of the differential impact of the two termination strategies on customers, those who are terminated using a hard approach are more likely to be affected more severely since they incur both social and economic losses. This is because, on top of feeling frustrated and betrayed, which are shown to cause loss of social resources such as status and esteem (Leary et al., 2006), the customers will also have to reinvest in economic resources such as time and effort (Bagozzi, 1975) to find an alternative service provider. But after a soft termination approach, customers only encounter social losses because the company already assists with the transition to a different provider. Therefore, a hard termination approach should be perceived as more severe than a soft approach, resulting in higher negative consequences.

\subsection{Conceptual Model}

The conceptual model (see figure 1) is anchored on the extant literature. Research across personal, organizational, and business relationships supports the notion that justice plays a key role in explaining people's reactions to conflict situations (Blodgett et al., 1994). Specifically, justice is the dominant theoretical framework in conventional service failures (Mohd-Any et al., 2019), but some studies suggest negative emotions such as betrayal may be equally important in explaining customers' reactions to termination (Lepthien et al., 2017). This is because service termination, which is a violation of marketplace norms (Haenlein and Kaplan, 2012), can elicit stronger negative reactions than conventional failures. Here, we 
draw on EVT to explain the way customers perceive and react to different service termination strategies. In line with previous research (e.g. see Mostafa et al., 2015) hypotheses are only developed for new relationships, but established links are also briefly discussed and tested.

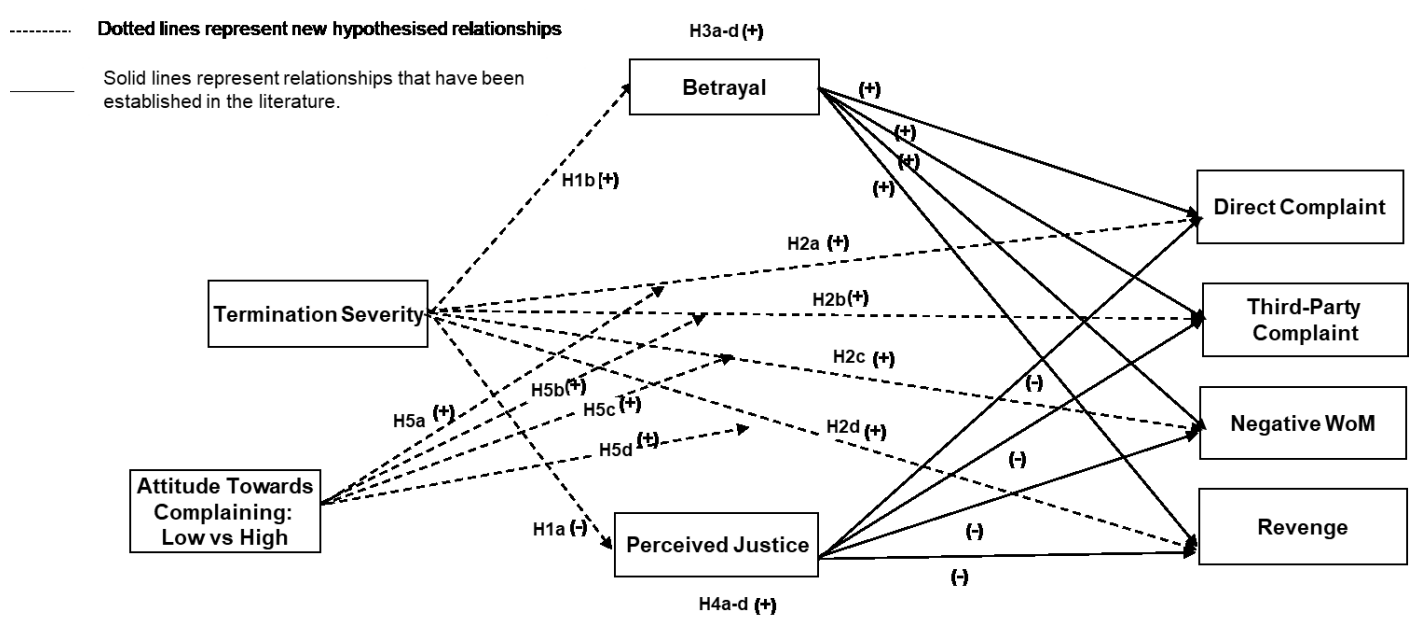

Figure 1. Conceptual Framework

\subsection{Direct effects of termination severity}

Perceived justice theory specifies that in an exchange relationship, customers expect the firm to "play fair" and keep its promises in providing a seamless service (Van Vaerenbergh et al., 2012: 264). But, when it fails to provide the service, the customers will form a negative perception of the focal firm. Prior research suggests that perceived severity can influence justice perceptions, For instance, a study by Nicklin and Williams (2009) shows that subjects who were exposed to the high severity condition had significantly lower perceived justice compared with those in the low severity condition. Here, we argue that using a more severe approach (hard instead of soft termination) will result in lower justice perceptions. This can be explained by equity perception which is defined as a comparison of one's output to input ratio with the company's output to input ratio (Mayser and Von Wangenheim, 2013). With the output of service termination remaining the same for both hard and soft approaches (i.e., customer relationships being terminated), the company increases its input in a soft approach 
(compared with a hard approach) by assisting the customer to move to an alternative service provider. Therefore, the output to input ratio of the company will decrease making the relationship between the company and its customer more equitable (Van Vaerenbergh et al., 2012). Consequently, using a more severe approach can lead to lower justice perceptions among terminated customers.

Perceived severity is also shown to influence betrayal (Grégoire and Fisher, 2008). Hess et al. (2003) indicate that a more severe failure will lead to greater intangible losses such as negative emotions. Similarly, Haenlein and Kaplan (2012) suggest that negative marketplace encounters such as service termination can cause stress and elicit negative emotions such as betrayal (Haenlein and Kaplan, 2012). Drawing on EVT, a negative expectancy violation can harm justice perceptions (Jones and Skarlicki, 2005) and negative emotions (Afifi and Metts, 1998), and the magnitude of the violation affects the intensity of reactions (Bevan et al., 2014). Therefore, a more (less) severe termination approach can inflict more (less) harm and result in lower perceived justice and higher perceived betrayal. Hence, we hypothesize:

H1: Termination severity negatively influences customer perceived justice (a) and betrayal (b).

The negative outcomes of terminating customer relationships have become more evident in recent years. For instance, service termination can damage a firm's image (Haenel et al., 2019, Lepthien et al., 2017, Sinha and Lu, 2019) and also firm retention and acquisition rates as a result of customers' negative reactions to service termination (Haenlein and Kaplan, 2010). Some of these negative outcomes are related to customers' negative behavioral reactions which can be broadly classified as customer complaint behavior (CCB). Singh 
(1988: 94) suggests that there are three categories of CCB: "voice" which is targeted at an external object directly involved in the exchange (e.g., complaining to the focal service provider), "third party" which is directed towards an external object who is not directly involved (e.g., complaining to legal agencies, newspapers, and blogs), and "private" or nWOM which is based on customers' internal social circle not directly involved in the exchange (e.g., negatively speaking about the firm with relatives and friends). Prior research shows that service termination can foster customer complaint behavior (Haenlein and Kaplan, 2012). Further, Mcquilken and Robertson (2011) show that failure severity is a strong predictor of CCB. Accordingly, termination severity can drive customers' negative behavioral reactions.

Customers may also decide to take revenge on the firm or its employees to release their negative emotions following a negative encounter (De Matos and Rossi, 2008). Grégoire et al. (2009) define revenge as customers' need to punish and cause harm to firms for the damages they have caused; they also find that perceived severity influences customers' desire for revenge. In a similar vein, Joireman et al. (2013) confirm that perceived severity can affect customers' revenge intentions. Service termination is also shown to foster revenge behavior (Haenel et al., 2019). Therefore, a more severe termination strategy can result in heightened revenge intentions. Hence, we hypothesize:

H2: Termination severity positively influences customer direct complaint (a), third party complaint (b), nWOM (c), and revenge (d) behavior.

\subsection{The mediating role of betrayal and justice}

Previous studies in service failure demonstrate that perceived betrayal positively influences customers' nWOM, direct, and third-party complaint behaviors (Grégoire and Fisher, 2008). Customers who experience negative emotions such as betrayal are also more likely to seek 
revenge (Bougie et al., 2003). Further, prior research suggests that perceived betrayal can mediate customer behavioral reactions to service failures. Specifically, in a termination context, Haenlein and Kaplan (2012) argue that service termination, as a violation of marketplace norms, can elicit strong negative emotional reactions such as betrayal which can subsequently mediate customer behavioral reactions. Similarly, Lepthien et al. (2017) propose that negative emotions can play an important role in mediating customer reactions to service termination. Therefore, we hypothesize:

H3: Betrayal mediates the relationship between termination severity and direct complaint (a), third party complaint (b), nWOM (c), and revenge (d) behavior.

Furthermore, research findings indicate that lack of justice can result in increased complaint behavior among customers experiencing service failures (Gong et al., 2014) or "nonpreferred differential treatment" such as termination (Mayser and Von Wangenheim, 2013, p. 99). In addition, perceived injustice is shown to trigger behavioral reactions such as revenge (Jones, 2009) and nWOM (Migacz et al., 2018). Specifically, in a termination context, perceived justice is shown to negatively influence customers' nWOM reactions (Lepthien et al., 2017). Therefore, we hypothesize:

H4: Perceived justice mediates the relationship between termination severity and direct complaint (a), third-party complaint (b), nWOM (c), and revenge (d) behavior.

\subsection{The moderating role of ATC}

ATC is defined as "the overall effect of goodness or badness of complaining to sellers" (Singh and Wilkes, 1996: 353). Existing studies demonstrate that ATC can moderate customers' reactions to service failures (Bambauer-Sachse and Rabeson, 2015, Kau and Loh, 
2006). Specifically, De Matos et al. (2009) show that those with higher ATC display higher post-failure negative behavioral reactions. This effect may be explained by the fact that people cope with transgressions differently (Endler and Parker, 1990). Coping strategies can be divided into problem-focused (such as complaining), emotion-focused (such as selfblame), and avoidance (such as leaving the situation and never returning) approaches. In the problem-focused approach, people take direct action with an external focus for blame attribution whereas, in the two other approaches, they remain silent either because they use self-deception with an internal focus of blame (emotion-focused) or simply do nothing because they think it is not worth the effort (avoidance) (Stephens and Gwinner, 1998).

Transferred to a termination context, those with high ATC tend to be problem-focused and take actions by either complaining or seeking revenge whereas those with low ATC opt for an emotion-focused or avoidance approach for coping with termination. Given that failure severity positively influences $\mathrm{CCB}$ and revenge behaviors and also those with high ATC are more likely to take action, we argue that the effects of termination severity on $\mathrm{CCB}$ and revenge will be stronger (weaker) for those with high (low) ATC. Therefore, we hypothesize:

H5: ATC moderates the relationships between termination severity and customer behavioral responses such that the effects of severity on direct complaint (a), third party complaint (b), nWOM (c) and revenge (d) will be stronger (weaker) among those with high (low) ATC.

\section{Methodology}

\subsection{Procedure and sample}

An experiment was used to test the hypothesized relationships. Retail banking was selected for the context of the study as it has been identified as one of the main service contexts where termination occurs (e.g., see Haenlein et al., 2007, Mittal et al., 2008). 822 adult consumers 
were recruited from a US-based online panel, but 76 cases were excluded from further analysis due to significantly low or high completion times. In terms of the sample composition, 51.6 were female, $48.4 \%$ were married, $52.8 \%$ were 45 years of age or older, and $59.4 \%$ of participants were college graduates.

The participants were randomly assigned to the experimental groups. Manipulation of the termination strategy type was operationalized as follows: for the hard termination strategy, the customer is informed that the bank is closing the customer's account and is giving two months' notice to the customer to make alternative arrangements. For the soft termination strategy, the customer is also informed of the account closure with the two months' notice period, but it is also added that the bank understands this might cause some inconvenience and is happy to assist the customer with moving to another bank. To enhance ecological validity in developing the scenarios, we relied on prior research (Lepthien et al., 2017, Mittal et al., 2008) as well as newspaper articles (Howard, 2012) and actual termination letters (see Table A3 in the online appendix).

In line with prior research (e.g. see Gelbrich et al., 2015), the success of the manipulation was checked before the main experiment through a pilot $(\mathrm{N}=97)$ with similar participants. We developed the following two items $(\alpha=0.89)$ to check the termination strategy manipulation: The bank tried to minimize the negative consequences for me; The bank offered to help me with the account closure. The result showed significant differences in the desired direction $\left(M_{\mathrm{Hard}}=2.49 ; M_{\mathrm{Soft}}=4.33, F[1,95]=57.81, p<.001\right)$. The scenario realism was also checked using two items from Gelbrich et al. (2015) (I believe that such incidents are likely to happen in real life; I think the description of the situation is realistic; $\alpha$ $=0.93)$. The scenarios were perceived as realistic and significantly higher than the scale midpoint $\left(M_{\text {Hard }}=5.13 ; M_{\text {Soft }}=5.07>4.00, p<.001\right)$. 


\subsection{Measures}

Existing measures were used from the literature to operationalize the variables in the conceptual framework (see Table A1. in the online appendix). Perceived justice was measured with four items (e.g., The outcome I received was not right; $\alpha=0.89$ ) adapted from Smith et al. (1999). Perceived severity was measured with three items (e.g., Mild issue: Severe issue; $\alpha=0.93$ ) from Hess et al. (2003). For betrayal, three items (e.g., I felt betrayed by the bank; $\alpha=0.95$ ) from Grégoire et al. (2009) were employed. Also, direct complaint (e.g., I want to ask the bank to take care of the problem; $\alpha=0.95$ ), third party complaint (e.g., I want to complain to a consumer agency and ask them to make the bank take care of the problem; $\alpha=0.93$ ) and nWOM (e.g., I would say negative things about the bank to other people; $\alpha=0.93$ ) were measured each with three items from Bougie et al. (2003). Revenge (five items; e.g., I want to get even with the bank; $\alpha=0.96$ ) and attitude towards complaining (three items; e.g., I am usually reluctant to complain; $\alpha=0.89$ ) were also measured with items from Grégoire et al. (2009) and Roschk and Gelbrich (2014), respectively. Control variables in this study include failure attribution (Gelbrich et al., 2015), service importance (Hess et al., 2003), and perceived intentionality (Varela-Neira et al., 2014) all measured with single items. Attribution and service importance are shown to influence severity (Webster and Sundaram, 1998), justice (Blodgett et al., 1994) and CCB (Van Vaerenbergh et al., 2012). In addition, perceived intentionality can also affect severity (Ames and Fiske, 2013), betrayal (Varela-Neira et al., 2014), and justice (Bies and Shapiro, 1987). Most of the items were measured using seven-point Likert scales (Cox, 1980) except perceived severity and service importance (where seven-point semantic differential scales were employed).

\section{Results}

A confirmatory factor analysis (CFA) was used to assess the quality of the factors using AMOS 26. Model fit indices show strong fit to the data (GFI $=0.96$, CFI $=0.99$, and 
RMSEA $=0.03)$ as recommended by $\mathrm{Hu}$ and Bentler (1999). Items were loading significantly on their relevant factors and the factor loadings were exceeding the 0.50 cut-off value which demonstrates convergent validity (Hair et al., 2010). The average variance extracted (AVE) for any two factors was greater than the squared correlation between the two factors (see Table A2 in the online appendix) which indicates discriminant validity (Fornell and Larcker, 1981). The reliability of the items was also established by examining the Cronbach alpha and composite reliability values which all exceeded the 0.7 threshold (Hair et al., 2010). Overall, all these suggest that this is a good measurement model. Finally, the structural equation model (SEM) as depicted in figure 1 was used to test the proposed hypotheses. The model shows an adequate fit to the data $(\mathrm{GFI}=0.97, \mathrm{CFI}=0.96$, and $\mathrm{RMSEA}=0.06)$.

Before formally testing our hypotheses, we compared the means of the perceived severity for the two termination strategy types. As expected, a hard termination approach results in higher perceived severity $\left(\mathrm{M}_{\text {Hard }}=6.10>\mathrm{M}_{\text {Soft }}=5.27 ; F[1,744]=39.37, p<.001\right)$. Next, we look at the results of the hypotheses tests.

\subsection{Direct effects}

As hypothesized, perceived termination severity negatively influences justice $(-.19, p<.001)$ and positively influences betrayal $(.37, p<.001)$. Therefore, hypotheses H1a and H1b are supported. Our results indicated that perceived termination severity positively influences direct complaint $(.16, p<.001)$ and third party complaint $(.22, p<.001)$, providing support for $\mathrm{H} 2 \mathrm{a}$ and $\mathrm{H} 2 \mathrm{~b}$. Our results also showed that termination severity negatively influences $\mathrm{nWOM}(.19, p<.001)$ and revenge $(.13, p<.01)$ behaviors, providing support for H2c and H2d. Consistent with previous research, we found support for the positive effects of betrayal on direct complaint $(.12, p<.01)$, third party complaint $(.20, p<.001)$, nWOM $(.44, p<$ $.001)$ and revenge $(.18, p<.001)$. In addition, the negative effect of justice was significant for 
direct complaint $(-.11, p<.01)$, third party complaint $(-.08, p<.05)$, nWOM $(-.14, p<.001)$, but not revenge $(-.06, p=.09)$.

\section{Insert Table 1 here}

\subsection{The mediating role of betrayal and justice}

We examined the mediating roles of betrayal and justice on the relationships between perceived severity and customers' behavioral responses. A summary of the results is provided in table 2. As hypothesized, the indirect effects of severity on direct complaint $(.06, p<.01)$, third party complaint $(.10, p<.001)$, nWOM $(.16, p<.001)$ and revenge $(.08, p<.001)$ through betrayal were significant. Therefore, H3a-H3d were all supported. Similarly, justice was mediating the relationships between severity and direct complaint $(.03, p<.01)$, third party complaint $(.02, p<.05)$, and nWOM $(.03, p<.01)$, but not for revenge $(.01, p=.06)$, thus providing support for $\mathrm{H} 4 \mathrm{a}-\mathrm{H} 4 \mathrm{c}$, but not for $\mathrm{H} 4 \mathrm{~d}$.

\section{Insert Table 2 here}

\subsection{The moderating effects of ATC}

We used AMOS 26 to examine the moderating role of ATC on the effects of termination severity on customers' behavioral responses using multi-group analysis. In line with previous studies (De Matos et al., 2009, Glikson et al., 2019, Voorhees and Brady, 2005), we used the ATC median score ( 4.00 which is the same as the scale midpoint) to divide the sample into two groups: those with low propensity to complain $(\mathrm{N}=344)$ and those with a high propensity to complain $(\mathrm{N}=402)$. The results of the moderation analysis are summarized in table 3.

Our results indicated that the positive effect of termination severity on direct complaint is only significant in the high ATC condition. To assess whether this effect was stronger in the high ATC group, we ran a chi-square difference test for the restricted and 
unrestricted models and the difference was significant $\left(\Delta \chi^{2}=7.76, \Delta \mathrm{df}=1, p<.01\right)$. Therefore, H5a is supported. The effect of termination severity on third party complaint was also only significant in the high ATC group. The chi-square difference test yielded significant result $\left(\Delta \chi^{2}=20.82 \Delta \mathrm{df}=1, p<.001\right)$, providing support for H5b. Our results also showed that termination severity positively influences nWOM in both low and high ATC conditions, although it was not significantly stronger in the high ATC group $\left(\Delta \chi^{2}=.82, \Delta \mathrm{df}=1, p=.37\right)$. Therefore, the moderating effect of ATC on the termination severity-nWOM link, as hypothesized in H5c, was not supported. Lastly, the effect of termination severity on revenge was not significant in the low ATC condition but was significant in the high ATC group, and similar to direct and third party complaint, the effect in the high ATC group was significantly stronger than the effect in the low ATC group. The chi-square difference test yielded significant result $\left(\Delta \chi^{2}=10.19, \Delta \mathrm{df}=1, p<.01\right)$, providing support for H5d.

\section{Insert Table 3 here}

\section{Discussion and implications}

\subsection{General discussion}

This study enhances our understanding of service termination as a phenomenon. Our results indicate that a hard termination strategy, which is shown to be more severe, leads to higher negative customer reactions compared with a soft approach. These findings improve our understanding of customers' perceptions of different termination strategies and suggest that contrary to prior findings (Haenlein and Kaplan, 2011), customers perceive and react to hard and soft termination approaches differently.

Perceived termination severity negatively influences customers' justice perceptions and positively influences customers' feelings of betrayal. The study also shows that perceived severity positively influences direct and third party complaint, nWOM, and revenge 
behaviors. According to justice theory, if firms provide a sensitive response to a severe firm transgression (e.g., by assisting customers to move to a different provider), this can help customers deal better with the situation, improve their evaluations and justice perceptions and also reduce their subsequent negative behavioral reactions while lack of an appropriate response can elicit negative emotions (Mittal et al., 2008, Roschk and Kaiser, 2013).

In addition, the findings extend prior research on the key role of perceived betrayal in driving customers' negative behavioral reactions. Specifically, while prior research highlights the role of justice as a key mediator of customers' reactions to service termination (Haenlein and Kaplan, 2010, Lepthien et al., 2017), the results show that betrayal appears to be a stronger predictor of customers' negative behavioral responses in a termination context.

This paper also explores the under-researched role of ATC and, in particular, its moderating effects on the relationships between termination severity and customer behavioral reactions. Our results indicate that ATC moderates the effects of severity on direct complaint, third party complaint, and revenge. While severity has no impact on direct and third party complaint as well as revenge intentions in the low ATC conditions, it significantly increases these negative behaviors in the high ATC group. Stephens and Gwinner (1998) suggest that people tend to use different strategies (i.e., problem-focused, emotion-focused, or avoidance) for coping with negative encounters. It appears that customers with low ATC tend to use an emotion-focused approach (i.e., blame themselves for a service termination incident) or avoidance approach (i.e., not wasting any effort and just leave) whereas those with high ATC are more likely to use a problem-focused approach (i.e., take actions by either complaining or getting even with the firm).

Interestingly, termination severity positively affects nWOM behavior in both low ATC and high ATC groups and the difference between the two groups is not significant. Based on Day and Landon's (1977) dichotomous classification of complaint behavior as 
public and private, these results suggest that, unlike public complaining where customers' attitudes drive their behavioral responses when it gets to private complaining, customers' attitudes don't hold them back from sharing their negative experience with their family and friends. This further highlights the importance of nWOM and how it can damage a firm's reputation (Haenlein and Kaplan, 2012, Lepthien et al., 2017) among other existing and prospective customers following a service termination incident.

\subsection{Theoretical contributions}

The first contribution of this study is to add to the limited body of research on service termination in a B2C context (Haenlein and Kaplan, 2010). In particular, this is the first study that provides a theoretical model of terminated customers' attitudinal, emotional, and behavioral reactions to different termination strategies. Contrary to previous findings by Haenlein and Kaplan (2011) which suggest that customers' responses to termination are irrespective of the termination strategy used, our results indicate that the termination approach significantly influences how customers perceive and react to service termination. Specifically, compared with a soft approach, a hard strategy is perceived as more severe and results in lower justice perceptions and a higher level of betrayal. It also leads to higher customer complaint and revenge intentions. These findings provide empirical support for prior conceptual research by Alajoutsijärvi et al. (2000) and Mittal et al. (2008) proposing that focusing on self-interest will lead to higher negative consequences in the long-term.

The second contribution of this study is to reveal the mechanism that explains the effects of termination severity on customers' behavioral responses. Contrary to previous findings that indicate justice to be the dominant predictor of customers negative behavioral responses to service failures (Blodgett et al., 1994, Tripp et al., 2007) and specifically, to service termination (Haenlein and Kaplan, 2010, Lepthien et al., 2017), this study highlights the important role of betrayal. In doing so, it responds to calls for research on the role of 
negative emotions in service termination (Haenel et al., 2019, Lepthien et al., 2017). Drawing on EVT, this study shows that following a firm-initiated service termination, which is considered as an intentional and severe violation of unexpressed marketplace norms (Haenlein and Kaplan, 2012), customers' negative emotions and in particular, feelings of betrayal is a stronger predictor of customers' reactions.

The third contribution of this study is examining an important customer-related boundary condition for the effects of termination severity on customer behavioral responses. This research extends De Matos et al.'s (2009) and Voorhees and Brady (2005) works by revealing that following service termination, ATC only moderates customers' public complaining (such as revenge, direct and third party complaint), but not their private complaining (such as nWOM) behaviors. Accordingly, those with higher ATC are more likely to show significantly higher public complaining behaviors than those with lower ATC, but there are no differences between low and high ATC groups in their private complaining.

\subsection{Managerial implication}

From a managerial perspective, this study also has two practical implications. First, while termination of relationships may seem an appropriate strategy to enhance a firm's financial performance (Shin et al., 2012), service managers should give more attention to the choice of termination strategy. It may be necessary for firms to terminate customer relationships, but the way they handle the situation is of paramount importance. Most service providers choose a direct hard approach. According to Baxter (1985), this is in line with the way most people break up in personal relationships (i.e., choosing the easiest option for themselves without considering the needs of the other party). While a hard approach might seem an easier and more convenient option in the short-term (Alajoutsijärvi et al., 2000), managers should beware of its negative impact on customers' attitudinal and behavioral responses. 
Second, our results reveal that even though a soft termination approach is perceived as a less severe approach compared with a hard approach, it does not prevent the subsequent negative behavioral responses. Given that firm-initiated service termination is an intentional failure, firms should find different ways to minimize the negative consequences of service termination for customers and subsequently reduce their negative behavioral reactions. This research supports the notion that managers should consider the customers' well-being at times of non-preferred differential treatment (Mayser and Von Wangenheim, 2013). Therefore, it is crucial that firms show empathy and care towards their customers and try to find a substitute to fix the problem (e.g., to migrate customers to a new service provider) to reduce customers' negative emotional and behavioral reactions.

\subsection{Limitations and future research}

This research has some limitations which can be addressed in future research. First, this study examined service termination in a contractual setting (banking), but there are also cases of termination in non-contractual settings. For instance, two sisters were banned from shopping in a US-wide clothes retailer (Haenlein and Kaplan, 2012), or customers were banned from restaurants for chronic complaining or inappropriate behavior (Angelowicz, 2017). It would be interesting to find out how customers in a non-contractual setting would perceive and react to the termination news.

Second, studies on termination of customer relationships have been conducted in western cultures, but there has been no attempt to validate the findings in markedly different cultures. Given that previous cross-cultural studies in services marketing clearly show that western models require regional modifications (Mattila, 1999, Schoefer et al., 2019), future research should examine how customers from distinctly different cultures (e.g., American versus East Asian) perceive and react to different termination strategies. This would help improve our understanding of the effectiveness of different termination strategies and will 
also help multinational companies tailor their strategies for terminating customer relationships accordingly.

Third, prior research has predominantly relied on experimental research to examine customers' reactions to service failures and termination. In line with recent calls for research to combine experimental with field data (Van Vaerenbergh et al., 2019), it would be interesting to review publicly available customer complaints about their account closures to find out more about customer recovery expectations and specifically among monetary compensation, explanation, and apology as the main recovery tools (Piehler et al., 2019), which one is considered as more desirable.

Lastly, future studies should examine other customer-related boundary conditions such as customer self-efficacy (Chen, 2018) and relationship quality (Gelbrich et al., 2016, Yildirim et al., 2018) as well as firm-related factors such as prior warning (Lepthien et al., 2017) and brand strength (Wang and Zhang, 2018) in influencing customers' reactions to service termination. Other moderators such as group size (individual vs. group termination) and perceived service importance (closure of main bank account vs. secondary bank account) may warrant further examination. 
Table 1. Summary of direct effect results

\begin{tabular}{|c|c|c|c|}
\hline Estimate Path & Expected sign & $\boldsymbol{\beta}$ & t-Value \\
\hline Termination Severity $\rightarrow$ Justice (H1a) & - & $-.19 * * *$ & -5.22 \\
\hline Termination Severity $\rightarrow$ Betrayal (H1b) & + & $.37 * * *$ & 11.36 \\
\hline Termination Severity $\rightarrow$ Direct Complaint (H2a) & + & $.16^{* * *}$ & 4.05 \\
\hline Termination Severity $\rightarrow$ Third Party Complaint (H2b) & + & $.22 * * *$ & 5.81 \\
\hline Termination Severity $\rightarrow$ NWOM (H2c) & + & $.19 * * *$ & 5.82 \\
\hline Termination Severity $\rightarrow$ Revenge (H2d) & + & $.13 * * *$ & 3.30 \\
\hline Betrayal $\rightarrow$ Direct Complaint & + & $.12 * *$ & 2.88 \\
\hline Betrayal $\rightarrow$ Third Party Complaint & + & $.20 * * *$ & 5.16 \\
\hline Betrayal $\rightarrow$ nWOM & + & $.44 * * *$ & 13.13 \\
\hline Betrayal $\rightarrow$ Revenge & + & $.18 * * *$ & 4.53 \\
\hline Justice $\rightarrow$ Direct Complaint & - & $-.11 * *$ & -3.03 \\
\hline Justice $\rightarrow$ Third Party Complaint & - & $-.08^{*}$ & -2.24 \\
\hline Justice $\rightarrow$ nWOM & - & $-.14 * * *$ & -4.38 \\
\hline Justice $\rightarrow$ Revenge & - & $-.06 \mathrm{~ns}$ & -1.70 \\
\hline
\end{tabular}


Table 2. Summary of mediation results

\begin{tabular}{|l|c|c|}
\hline Hypothesis & Hypothesis & Indirect Effect \\
\hline Termination Severity $\rightarrow$ Betrayal $\rightarrow$ Direct Complaint & $\mathrm{H} 3 \mathrm{a}$ & $.06^{* *}$ \\
\hline Termination Severity $\rightarrow$ Betrayal $\rightarrow$ Third Party Complaint & $\mathrm{H} 3 \mathrm{~b}$ & $.10^{* * *}$ \\
\hline Termination Severity $\rightarrow$ Betrayal $\rightarrow$ nWOM & $\mathrm{H} 3 \mathrm{c}$ & $.16^{* * *}$ \\
\hline Termination Severity $\rightarrow$ Betrayal $\rightarrow$ Revenge & $\mathrm{H} 3 \mathrm{~d}$ & $.08^{* * *}$ \\
\hline Termination Severity $\rightarrow$ Justice $\rightarrow$ Direct Complaint & $\mathrm{H} 4 \mathrm{a}$ & $.03^{* *}$ \\
\hline Termination Severity $\rightarrow$ Justice $\rightarrow$ Third Party Complaint & $\mathrm{H} 4 \mathrm{~b}$ & $.02^{*}$ \\
\hline Termination Severity $\rightarrow$ Justice $\rightarrow$ nWOM & $\mathrm{H} 4 \mathrm{c}$ & $.03^{* *}$ \\
\hline Termination Severity $\rightarrow$ Justice $\rightarrow$ Revenge & $\mathrm{H} 4 \mathrm{~d}$ & $.01 \mathrm{~ns}$ \\
\hline
\end{tabular}

Note $n s=$ not significant; $*=p<0.05 ; * *=p<0.01 ; * * *=p<0.001$. 
Table 3. Summary of moderation results

\begin{tabular}{|l|c|c|c|c|}
\hline & & Low & High & Differences \\
& & ATC & ATC & \\
\hline Estimate Path & Hypothesis & B & B & $\Delta \chi^{2}$ (P-value) \\
\hline Termination Severity $\rightarrow$ Direct Complaint & H5a & $.08 \mathrm{~ns}$ & $.33^{* * *}$ & $7.76(p<.01)$ \\
\hline Termination Severity $\rightarrow$ Third party Complaint & H5b & $.10 \mathrm{~ns}$ & $.50^{* * *}$ & $20.82(p<.001)$ \\
\hline Termination Severity $\rightarrow$ nWOM & H5c & $.20^{* * *}$ & $.15^{* *}$ & $.82(p=.37)$ \\
\hline Termination Severity $\rightarrow$ Revenge & H5d & $.02 \mathrm{~ns}$ & $.31^{* * *}$ & $10.19(p<.01)$ \\
\hline
\end{tabular}

Note $\mathrm{n} s=$ not significant $; *=p<0.05 ; * *=p<0.01 ; * * *=p<0.001$. B: unstandardized coefficient. Sample size: $\mathrm{N}_{\text {Low ATC }}=344, \mathrm{~N}_{\text {High ATC }}=402$. 


\section{References}

Afifi, W. A. and Metts, S. (1998), "Characteristics and Consequences of Expectation Violations in Close Relationships". Journal of Social and Personal Relationships, Vol. 15 No. 3, pp. 365-392.

Alajoutsijärvi, K., Möller, K. and Tähtinen, J. (2000), "Beautiful Exit: How to Leave Your Business Partner". European Journal of Marketing, Vol. 34 No. 11/12, pp. 12701290.

Ames, D. L. and Fiske, S. T. (2013), "Intentional Harms Are Worse, Even When They're Not". Psychological Science, Vol. 24 No. 9, pp. 1755-1762.

Angelowicz, A. 2017. 10 Celebs' Reportedly Odd Behavior at Restaurants. Available: http://edition.cnn.com/2010/LIVING/wayoflife/05/03/tf.celebs.bad.reps.restaurants/ [Accessed 12th June 2017].

Bachman, G. F. and Guerrero, L. K. (2006), "Relational Quality and Communicative Responses Following Hurtful Events in Dating Relationships: An Expectancy Violations Analysis". Journal of Social and Personal Relationships, Vol. 23 No. 6, pp. 943-963.

Bagozzi, R. P. (1975), "Marketing as Exchange". The Journal of Marketing, Vol. 39 No. 4, pp. 32-39.

Balaji, M. and Sarkar, A. (2013), "Does Successful Recovery Mitigate Failure Severity? A Study of the Behavioral Outcomes in Indian Context". International Journal of Emerging Markets, Vol. 8 No. 1, pp. 65-81.

Bambauer-Sachse, S. and Rabeson, L. (2015), "Determining Adequate Tangible Compensation in Service Recovery Processes for Developed and Developing Countries: The Role of Severity and Responsibility". Journal of Retailing and Consumer Services, Vol. 22 No. January, pp. 117-127.

Baxter, L. A., (1985), Accomplishing Relationship Disengagement. In S. Duck \& D. Perlman (Eds.), (1985). Understanding Personal Relationships: An Interdisciplinary Approach, (pp. 243-265). Sage Publications.

Bettencourt, B. and Manning, M. (2016), "Negatively Valenced Expectancy Violation Predicts Emotionality: A Longitudinal Analysis". Emotion, Vol. 16 No. 6, pp. 787.

Bevan, J. L., Ang, P.-C. and Fearns, J. B. (2014), "Being Unfriended on Facebook: An Application of Expectancy Violation Theory". Computers in Human Behavior, Vol. 33 No., pp. 171-178. 
Bies, R. J. and Shapiro, D. L. (1987), "Interactional Fairness Judgments: The Influence of Causal Accounts". Social Justice Research, Vol. 1 No. 2, pp. 199-218.

Blodgett, Granbois and Walters. (1994), "The Effects of Perceived Justice on Complainants' Negative Word-of-Mouth Behavior and Repatronage Intentions". Journal of Retailing, Vol. 69 No. 4, pp. 399-428.

Bougie, R., Pieters, R. and Zeelenberg, M. (2003), "Angry Customers Don't Come Back, They Get Back: The Experience and Behavioral Implications of Anger and Dissatisfaction in Services". Journal of the Academy of Marketing Science, Vol. 31 No. 4, pp. 377-393.

Burgoon, J. K. (1993), "Interpersonal Expectations, Expectancy Violations, and Emotional Communication". Journal of Language and Social Psychology, Vol. 12 No. 1-2, pp. $30-48$.

Casidy, R. and Shin, H. (2015), "The Effects of Harm Directions and Service Recovery Strategies on Customer Forgiveness and Negative Word-of-Mouth Intentions". Journal of Retailing and Consumer Services, Vol. 27 No., pp. 103-112.

Chen, C.-Y. (2018), "How Customer Participation Influences Service Failure Attribution". Journal of Service Theory and Practice, Vol. 28 No. 3, pp. 298-314.

Cooper, R. and Kaplan, R. S. (1991), "Profit Priorities from Activity-Based Costing". Harvard Business Review, Vol. 69 No. 3, pp. 130-135.

Cox, E. P. (1980), "The Optimal Number of Response Alternatives for a Scale: A Review". Journal of Marketing Research, Vol. 17 No. 4, pp. 407-422.

Day, R. L. and Landon, E. L. (1977), "Toward a Theory of Consumer Complaining Behavior". Consumer and Industrial Buying Behavior, Vol. 95 No. 1, pp. 425-437.

De Matos, C. A. and Rossi, C. a. V. (2008), "Word-of-Mouth Communications in Marketing: A Meta-Analytic Review of the Antecedents and Moderators". Journal of the Academy of Marketing Science, Vol. 36 No. 4, pp. 578-596.

De Matos, C. A., Rossi, C. a. V., Veiga, R. T. and Vieira, V. A. (2009), "Consumer Reaction to Service Failure and Recovery: The Moderating Role of Attitude toward Complaining". Journal of Services Marketing, Vol. 23 No. 7, pp. 462-475.

Endler, N. S. and Parker, J. D. (1990), "Multidimensional Assessment of Coping: A Critical Evaluation". Journal of Personality and Social Psychology, Vol. 58 No. 5, pp. 844.

Fornell, C. and Larcker, D. F. (1981), "Evaluating Structural Equation Models with Unobservable Variables and Measurement Error". Journal of Marketing Research, Vol. 18 No. 1, pp. 39-50. 
Gelbrich, K., Gäthke, J. and Grégoire, Y. (2015), "How Much Compensation Should a Firm Offer for a Flawed Service? An Examination of the Nonlinear Effects of Compensation on Satisfaction". Journal of Service Research, Vol. 18 No. 1, pp. 107123.

Gelbrich, K., Gäthke, J. and Grégoire, Y. (2016), "How a Firm's Best Versus Normal Customers React to Compensation after a Service Failure". Journal of Business Research, Vol. 69 No. 10, pp. 4331-4339.

Glikson, E., Rees, L., Wirtz, J., Kopelman, S. and Rafaeli, A. (2019), "When and Why a Squeakier Wheel Gets More Grease: The Influence of Cultural Values and Anger Intensity on Customer Compensation". Journal of Service Research, Vol. 22 No. 3, pp. 223-240.

Gong, T. and Wang, C.-Y. (2019), "How Does Dysfunctional Customer Behavior Affect Employee Turnover". Journal of Service Theory and Practice, Vol. 29 No. 3, pp. 329-352.

Gong, T., Yi, Y. and Choi, J. N. (2014), "Helping Employees Deal with Dysfunctional Customers the Underlying Employee Perceived Justice Mechanism". Journal of Service Research, Vol. 17 No. 1, pp. 102-116.

Grégoire, Y. and Fisher, R. J. (2008), "Customer Betrayal and Retaliation: When Your Best Customers Become Your Worst Enemies". Journal of the Academy of Marketing Science, Vol. 36 No. 2, pp. 247-261.

Grégoire, Y., Tripp, T. M. and Legoux, R. (2009), "When Customer Love Turns into Lasting Hate: The Effects of Relationship Strength and Time on Customer Revenge and Avoidance". Journal of Marketing, Vol. 73 No. 6, pp. 18-32.

Haenel, C. M., Wetzel, H. A. and Hammerschmidt, M. (2019), "The Perils of Service Contract Divestment: When and Why Customers Seek Revenge and How It Can Be Attenuated". Journal of Service Research, Vol. 22 No. 3, pp. 301-322.

Haenlein, M. and Kaplan, A. M. (2009), "Unprofitable Customers and Their Management". Business Horizons, Vol. 52 No. 1, pp. 89-97.

Haenlein, M. and Kaplan, A. M. (2010), "An Empirical Analysis of Attitudinal and Behavioral Reactions toward the Abandonment of Unprofitable Customer Relationships". Journal of Relationship Marketing, Vol. 9 No. 4, pp. 200-228.

Haenlein, M. and Kaplan, A. M. (2011), "Evaluating the Consequences of Abandoning Unprofitable Customers: A Comparison of Direct and Indirect Abandonment Strategies". Zeitschrift fuer Betriebswirtschaft, Vol. 81 No. 2, pp. 77-94. 
Haenlein, M. and Kaplan, A. M. (2012), "The Impact of Unprofitable Customer Abandonment on Current Customers' Exit, Voice, and Loyalty Intentions: An Empirical Analysis". Journal of Services Marketing, Vol. 26 No. 6, pp. 458-470.

Haenlein, M., Kaplan, A. M. and Beeser, A. J. (2007), "A Model to Determine Customer Lifetime Value in a Retail Banking Context". European Management Journal, Vol. 25 No. 3, pp. 221-234.

Hair, J. F., Black, W. C., Babin, B. J., Anderson, R. E. and Tatham, R. (2010). Multivariate Data Analysis: A Global Perspective, New York, Pearson,.

Hess, R. L., Ganesan, S. and Klein, N. M. (2003), "Service Failure and Recovery: The Impact of Relationship Factors on Customer Satisfaction". Journal of the Academy of Marketing Science, Vol. 31 No. 2, pp. 127-145.

Howard, B. 2012. Bank Account Closures 'Unjust' [Online]. Available: http://www.bbc.co.uk/news/business-18540832 [Accessed 8th November 2014].

Hu, L. T. and Bentler, P. M. (1999), "Cutoff Criteria for Fit Indexes in Covariance Structure Analysis: Conventional Criteria Versus New Alternatives". Structural Equation Modeling: A Multidisciplinary Journal, Vol. 6 No. 1, pp. 1-55.

Joireman, J., Grégoire, Y., Devezer, B. and Tripp, T. M. (2013), "When Do Customers Offer Firms a "Second Chance" Following a Double Deviation? The Impact of Inferred Firm Motives on Customer Revenge and Reconciliation". Journal of Retailing, Vol. 89 No. 3, pp. 315-337.

Jones, D. A. (2009), "Getting Even with One's Supervisor and One's Organization: Relationships among Types of Injustice, Desires for Revenge, and Counterproductive Work Behaviors". Journal of Organizational Behavior, Vol. 30 No. 4, pp. 525-542.

Jones, D. A. and Skarlicki, D. P. (2005), "The Effects of Overhearing Peers Discuss an Authority's Fairness Reputation on Reactions to Subsequent Treatment". Journal of Applied Psychology, Vol. 90 No. 2, pp. 363.

Kabue, H. W., Gathenya, J. W. and Kihoro, J. M. (2015), "Customer Relationship Termination and Marketing Effectiveness in Commercial Banks". International Journal of Business and Social Science, Vol. 6 No. 10, pp.

Kau, A.-K. and Loh, E. W.-Y. (2006), "The Effects of Service Recovery on Consumer Satisfaction: A Comparison between Complainants and Non-Complainants". Journal of Services Marketing, Vol. 20 No. 2, pp. 101-111. 
King, B. 2013. When Hsbc Closes Your Bank Account without Telling You [Online]. Available: $\quad$ http://www.huffingtonpost.com/brett-king/when-hsbc-closes-yourban b 4362504.html [Accessed 06 July 2015].

Leary, M. R., Twenge, J. M. and Quinlivan, E. (2006), "Interpersonal Rejection as a Determinant of Anger and Aggression". Personality and Social Psychology Review, Vol. 10 No. 2, pp. 111-132.

Lepthien, A., Papies, D., Clement, M. and Melnyk, V. (2017), "The Ugly Side of Customer Management-Consumer Reactions to Firm-Initiated Contract Terminations". International Journal of Research in Marketing, Vol. 34 No. 4, pp. 829-850.

Mattila, A. S. (1999), "The Role of Culture in the Service Evaluation Process". Journal of Service Research, Vol. 1 No. 3, pp. 250-261.

Mayser, S. and Von Wangenheim, F. (2013), "Perceived Fairness of Differential Customer Treatment Consumers' Understanding of Distributive Justice Really Matters". Journal of Service Research, Vol. 16 No. 1, pp. 99-113.

Mcquilken, L. and Robertson, N. (2011), "The Influence of Guarantees, Active Requests to Voice and Failure Severity on Customer Complaint Behavior". International Journal of Hospitality Management, Vol. 30 No. 4, pp. 953-962.

Migacz, S. J., Zou, S. and Petrick, J. F. (2018), "The "Terminal” Effects of Service Failure on Airlines: Examining Service Recovery with Justice Theory". Journal of Travel Research, Vol. 57 No. 1, pp. 83-98.

Mittal, V., Sarkees, M. and Murshed, F. (2008), "The Right Way to Manage Unprofitable Customers". Harvard Business Review, Vol. 86 No. 4, pp. 94-103.

Mohd-Any, A. A., Mutum, D. S., Ghazali, E. M. and Mohamed-Zulkifli, L. (2019), "To Fly or Not to Fly? An Empirical Study of Trust, Post-Recovery Satisfaction and Loyalty of Malaysia Airlines Passengers". Journal of Service Theory and Practice, Vol. 29 No. 5/6, pp. 661-690.

Mostafa, R. B., Lages, C. R., Shabbir, H. A. and Thwaites, D. (2015), "Corporate Image a Service Recovery Perspective". Journal of Service Research, Vol. 18 No. 4, pp. 468483.

Narayanan, V. and Kaplan, R. S. (2001), "Measuring and Managing Customer Profitability". Journal of Cost Management, Vol. 15 No. 5, pp. 5-15.

Nicklin, J. M. and Williams, K. J. (2009), "Reactions to Others' Mistakes: An Empirical Test of Fairness Theory". The Journal of Psychology, Vol. 143 No. 5, pp. 533-558. 
Niraj, R., Gupta, M. and Narasimhan, C. (2001), "Customer Profitability in a Supply Chain". Journal of Marketing, Vol. 65 No. 3, pp. 1-16.

Piehler, R., Schade, M., Hanisch, I. and Burmann, C. (2019), "Reacting to Negative Online Customer Reviews". Journal of Service Theory and Practice, Vol. 29 No. 4, pp. 401414.

Reinartz, W. and Kumar, V. (2002), "The Mismanagement of Customer Loyalty". Harvard Business Review, Vol. 80 No. 7, pp. 86-94, 125.

Roschk, H. and Gelbrich, K. (2014), "Identifying Appropriate Compensation Types for Service Failures a Meta-Analytic and Experimental Analysis". Journal of Service Research, Vol. 17 No. 2, pp. 195-211.

Roschk, H. and Kaiser, S. (2013), "The Nature of an Apology: An Experimental Study on How to Apologize after a Service Failure". Marketing Letters, Vol. 24 No. 3, pp. 293-309.

Schoefer, K. and Ennew, C. (2005), "The Impact of Perceived Justice on Consumers' Emotional Responses to Service Complaint Experiences". Journal of Services Marketing, Vol. 19 No. 5, pp. 261-270.

Schoefer, K., Wäppling, A., Heirati, N. and Blut, M. (2019), "The Moderating Effect of Cultural Value Orientations on Behavioral Responses to Dissatisfactory Service Experiences". Journal of Retailing and Consumer Services, Vol. 48 No., pp. 247256.

Shin, J., Sudhir, K. and Yoon, D.-H. (2012), "When to "Fire" Customers: Customer CostBased Pricing". Management Science, Vol. 58 No. 5, pp. 932-947.

Singh, J. (1988), "Consumer Complaint Intentions and Behavior: Definitional and Taxonomical Issues". The Journal of Marketing, Vol. 52 No. 1, pp. 93-107.

Singh, J. and Wilkes, R. E. (1996), "When Consumers Complain: A Path Analysis of the Key Antecedents of Consumer Complaint Response Estimates". Journal of the Academy of Marketing Science, Vol. 24 No. 4, pp. 350-365.

Sinha, J. and Lu, F.-C. (2019), "Ignored or Rejected: Retail Exclusion Effects on Construal Levels and Consumer Responses to Compensation". Journal of Consumer Research, Vol. 46 No. 4, pp. 791-807.

Smith, A. K., Bolton, R. N. and Wagner, J. (1999), "A Model of Customer Satisfaction with Service Encounters Involving Failure and Recovery". Journal of Marketing Research, Vol. 36 No. 3, pp. 356-372. 
Stephens, N. and Gwinner, K. P. (1998), "Why Don’t Some People Complain? A CognitiveEmotive Process Model of Consumer Complaint Behavior". Journal of the Academy of Marketing Science, Vol. 26 No. 3, pp. 172-189.

Swanson, S. R. and Hsu, M. K. (2009), "Critical Incidents in Tourism: Failure, Recovery, Customer Switching, and Word- of- Mouth Behaviors". Journal of Travel \& Tourism Marketing, Vol. 26 No. 2, pp. 180-194.

Tahtinen, J. and Halinen, A. (2002), "Research on Ending Exchange Relationships: A Categorization, Assessment and Outlook". Marketing Theory, Vol. 2 No. 2, pp. 165188.

Tripp, T. M., Bies, R. J. and Aquino, K. (2007), "A Vigilante Model of Justice: Revenge, Reconciliation, Forgiveness, and Avoidance". Social Justice Research, Vol. 20 No. 1, pp. 10-34.

Van Vaerenbergh, Y., Larivière, B. and Vermeir, I. (2012), "The Impact of Process Recovery Communication on Customer Satisfaction, Repurchase Intentions, and Word-ofMouth Intentions". Journal of Service Research, Vol. 15 No. 3, pp. 262-279.

Van Vaerenbergh, Y., Varga, D., De Keyser, A. and Orsingher, C. (2019), "The Service Recovery Journey: Conceptualization, Integration, and Directions for Future Research". Journal of Service Research, Vol. 22 No. 2, pp. 103-119.

Varela-Neira, C., Vázquez-Casielles, R. and Iglesias, V. (2014), "Intentionality Attributions and Humiliation: The Impact on Customer Behavior". European Journal of Marketing, Vol. 48 No. 5/6, pp. 901-923.

Voorhees, C. M. and Brady, M. K. (2005), "A Service Perspective on the Drivers of Complaint Intentions". Journal of Service Research, Vol. 8 No. 2, pp. 192-204.

Wang, X. and Zhang, Q. (2018), "Does Online Service Failure Matter to Offline Customer Loyalty in the Integrated Multi-Channel Context? The Moderating Effect of Brand Strength". Journal of Service Theory and Practice, Vol. 28 No. 6, pp. 774-806.

Webster, C. and Sundaram, D. S. (1998), "Service Consumption Criticality in Failure Recovery". Journal of Business Research, Vol. 41 No. 2, pp. 153-159.

Yildirim, C., Oflaç, B. S. and Yurt, O. (2018), "The Doer Effect of Failure and Recovery in Multi-Agent Cases: Service Supply Chain Perspective". Journal of Service Theory and Practice, Vol. 28 No. 3, pp. 274-297.

Zeithaml, V. A., Rust, R. T. and Lemon, K. N. (2001), "The Customer Pyramid: Creating and Serving Profitable Customers". California Management Review, Vol. 43 No. 4, pp. 118-142. 


\section{Online Appendix}

Table A.1 Measurement Model Results

\begin{tabular}{|c|c|c|c|c|c|}
\hline Constructs and measurement items & $\lambda$ & AVE & CR & $\mathbf{M}$ & SD \\
\hline Perceived Justice $(\alpha=0.89 ;$ r-squared $=.12)$. & & .73 & .89 & 2.60 & 1.41 \\
\hline The account closure was not fair. (R) & .84 & & & & \\
\hline I did not get what I deserved. (R) & .86 & & & & \\
\hline In resolving the account closure, the bank gave me what I needed. * & - & & & & \\
\hline The outcome I received was not right.(R) & .86 & & & & \\
\hline Perceived Severity $(\alpha=0.93)$ & & .82 & .93 & 5.71 & 1.29 \\
\hline Mild issue : Severe issue & .92 & & & & \\
\hline Major issue : Minor issue $(\mathrm{R})$ & .92 & & & & \\
\hline Insignificant issue : Significant issue & .88 & & & & \\
\hline Betrayal $(\alpha=0.95 ;$ r-squared $=.12)$ & & .86 & .95 & 5.45 & 1.36 \\
\hline I felt betrayed by the bank. & .94 & & & & \\
\hline The bank broke the promise made to me. & .89 & & & & \\
\hline The bank let me down. & .95 & & & & \\
\hline Negative Word of Mouth $(\alpha=0.93 ;$ r-squared $=.52)$ & & .84 & .94 & 5.77 & 1.28 \\
\hline Say negative things about the bank to other people. & .83 & & & & \\
\hline Not recommend the bank to someone who seeks my advice. & .94 & & & & \\
\hline Discourage friends and relatives to do business with the bank. & .97 & & & & \\
\hline Direct Complaint $(\alpha=0.95 ;$ r-squared $=.15)$ & & .87 & .95 & 4.88 & 1.73 \\
\hline Ask the bank to take care of the problem. & .94 & & & & \\
\hline Complain to the bank about the way I was treated. & .93 & & & & \\
\hline Discuss the problem with the bank. & .93 & & & & \\
\hline Third Party Complaint $(\alpha=0.93 ;$ r-squared $=.21)$ & & .82 & .93 & 4.05 & 1.72 \\
\hline $\begin{array}{l}\text { Complain to a consumer agency and ask them to make the bank take } \\
\text { care of the problem. }\end{array}$ & .89 & & & & \\
\hline Write a letter to a local newspaper about my bad experience. & .93 & & & & \\
\hline Take some legal action against the bank. & .90 & & & & \\
\hline Revenge $(\alpha=0.96 ;$ r-squared $=.18)$ & & .84 & .96 & 3.37 & 1.58 \\
\hline Take actions to get the bank in trouble. & .89 & & & & \\
\hline Punish the bank in some way. & .94 & & & & \\
\hline Cause inconvenience to the bank. & .90 & & & & \\
\hline Get even with the bank. & .94 & & & & \\
\hline Make the bank get what it deserves. & .91 & & & & \\
\hline Attitude Towards Complaining $(\alpha=0.89)$ & & .72 & .88 & 4.05 & 1.50 \\
\hline I am usually reluctant to complain. (R) & .87 & & & & \\
\hline In general, I avoid filing complaints. (R) & .83 & & & & \\
\hline I am less likely to complain than most people I know. (R) & .84 & & & & \\
\hline
\end{tabular}

Note: $\lambda=$ Standardized loadings; $\mathrm{M}=$ Mean; $\mathrm{SD}=$ Standard Deviation; $\alpha=$ Cronbach's alpha; $\mathrm{CR}=$ composite reliability; AVE=average variance extracted (Hair et al., 2010); $\mathrm{R}=$ Reverse-coded item; *= item deleted. 
Table A2. Factor Correlations

\begin{tabular}{|c|c|c|c|c|c|c|c|c|}
\hline & Severity & Justice & Revenge & nWoM & $\begin{array}{c}\text { Direct } \\
\text { Complaint }\end{array}$ & $\begin{array}{l}\text { Third Party } \\
\text { Complaint }\end{array}$ & Betrayal & $\begin{array}{c}\text { Attitude } \\
\text { Towards } \\
\text { Complaining }\end{array}$ \\
\hline Severity & 0.91 & & & & & & & \\
\hline Justice & -0.26 & 0.85 & & & & & & \\
\hline Revenge & 0.24 & -0.16 & 0.92 & & & & & \\
\hline nWoM & 0.44 & -0.35 & 0.24 & 0.92 & & & & \\
\hline $\begin{array}{c}\text { Direct } \\
\text { Complaint }\end{array}$ & 0.25 & -0.21 & 0.50 & 0.21 & 0.93 & & & \\
\hline $\begin{array}{l}\text { Third Party } \\
\text { Complaint }\end{array}$ & 0.35 & -0.21 & 0.62 & 0.32 & 0.66 & 0.91 & & \\
\hline Betrayal & 0.46 & -0.36 & 0.27 & 0.59 & 0.24 & 0.34 & 0.93 & \\
\hline $\begin{array}{r}\text { Attitude Toward } \\
\text { Complaining }\end{array}$ & 0.13 & -0.06 & 0.41 & 0.15 & 0.51 & 0.54 & 0.11 & 0.85 \\
\hline
\end{tabular}

Note: *The values on the diagonal are the square root of AVE. 
Table A3. Indicative sources for development of the experimental stimuli

\begin{tabular}{|l|c|}
\hline Link & Type \\
\hline$\underline{\text { https://www.bbc.co.uk/news/business-18540832 }}$ & Media \\
\hline$\underline{\text { https://www.theguardian.com/money/2015/mar/07/natwest-shut- }}$ & Newspaper \\
\hline$\underline{\text { customers-accounts }}$ & article \\
\hline$\underline{\text { https://www.thesun.co.uk/money/8347150/bank-account- }}$ & Newspaper \\
\hline closure-complaints-rise-your-rights/ & article \\
\hline$\underline{\text { https://www.theguardian.com/money/2018/feb/03/natwest- }}$ & Newspaper \\
\hline closed-my-account-with-no-explanation & article \\
\hline
\end{tabular}

